\title{
Relationship between symptoms of dyspnea, cough and chromosomal imbalance
}

\author{
Osman Demirhan ${ }^{*}$, Sedat Kuleci ${ }^{2}$ and Oya Baydar ${ }^{2}$ \\ ${ }^{1}$ Department of Medical Biology and Genetics, Çukurova University, Adana/Turkey \\ ${ }^{2}$ Department of Chest Diseases, Faculty of Medicine, Çukurova University, Adana/Turkey
}

\begin{abstract}
Objectives: Genetic instability is one of the basic reasons for the survival. In this study, a very high genetic imbalance that is inconsistent with cough and life can not be explained with our current genetic information.

Materials and methods: We performed cytogenetic analysis by G-banding in an adult girl, aged 23 years, with hundreds of chromosomal abnormalities (CAs). While she has been evaluating for diffuse parenchymal lung disease (DPLD), was considered to have a possible genetic disorder.

Results: We observed that there was at least one or more structural and/or numerical CAs in a cell of a person. The numerical and structural aberrations were found in $94.3 \%$ of cells analyzed. These CAs were a very serious and very important genetic instability. However, these hundreds of CAs had reflected to clinic appearence with the symptom of dyspnea, cough for the last 5 months, atypical facial and growth retardation.
\end{abstract}

Conclusion: There is a relationship between chromosome damage and symptoms of dyspnea, cough. We are in an inappropriate situation with normal mitosis. It needs to be investigated and explained.

\section{Introduction}

Genome stability is a primary importance for the survival and proper functioning of all organisms, and is caused by DNA damage, aberrant DNA replication or uncoordinated cell division, which can lead to CAs and gene mutations. Although chromosomal changes are highly variable, they can be grouped into two general categories; in balanced structural changes and in nonreciprocal or unbalanced structural changes. In balanced structural changes, the genetic material is exchanged evenly. Conversely, in nonreciprocal or unbalanced structural changes, the exchange is not equal, and genetic material is added or lost. This can range from the loss or gain of a single base pair to the loss or gain of entire chromosomes. Double-stranded breaks in DNA are important threats to genome integrity because they can result in CAs that can affect, simultaneously, many genes, and lead to cell malfunctioning and cell death. Recently, unexpected links between these double-stranded break-repair systems, and several human genome instability and cancer predisposition syndromes, have emerged. Mutations in human DNA repair genes, which maintain genomic integrity, can also deregulate normal cellular processes and allow additional proliferation mutations to occur [1]. Disregulation of normal genes can therefore contribute to the conversion of normal cells into cancerous cells. Scientists have hypothesized that the primary pathogenetic changes in cancer result from balanced rearrangements. Here, we review the hundreds of CAs in a person with atypical facial and growth retardation.

\section{Materials and methods}

\section{Clinical symptoms}

The twenty-three years old, non-smoker female patient has admitted to Department of Chest Diseases with the symptom of dyspnea and cough for the last 5 months. Dsypnea has been occured even with regular exercise. It did not affect by sleep and various envoirmental conditions, like dust and noxious particles. During this period, a persistent dry cough has accomponied. In her personel history, she had not reported any other diseases, except allergic eczema and growth retardation and there was no reported disorder in her family history, also. On her physical examination, she had no apperent findings except bilaterally high-pitched ronchi on auscultation. Chest $\mathrm{x}$-ray revealed consolidation area on right middle zone. On her thorax computerised tomography (CT), it was reported as: "bilateral widespread reticulonodular opacities, bronchiectasis and subpleural linear opacities". She was unable to perform pulmonary function tests (PFT) (Figure 1). Arterial blood gas examination was in normal limits, also. Due to growth retardation and physical appearence, she was consultated to Department of Genetics. She refused to join any procedures related with Department of Chest Diseases, including fiberoptic bronchoscopy and any other biopsy procuedures. She was discharged from hospital, but she was followed by Department of Genetics- After a while, she had an open lung biopsy in another hospital by a chest surgeon. Pathological finding of that biopsy had been reported as follows: "oedema, inflammatory granulation tissue." After surgical procedure, an unresolved pneumothorax had been evolved. The patient died at the age of 23 after treatment.

${ }^{\star}$ Correspondence to: Osman Demirhan, Department of Medical Biology and Genetics, Faculty of Medicine, Çukurova University, 01330 Balcalı-Adana, Turkey, Tel: 903223387140, Fax: 90-322-3386572,E-mail: osdemir@cu.edu.tr

Key words: The symptoms of dyspnea, cough, chromosomal abnormalities

Received: March 04, 2019; Accepted: March 21, 2019; Published: March 25, 2019 


\section{Cytogenetic analysis}

Firstly, patient has been seen and diagnosed by the Departments of Chest Diseases and then they were referred to Department of Medical Biology and Genetics, Faculty of Medicine, Çukurova University for cytogenetic analyses. Peripheral blood was taken from the patient and her parents for culture studies. A $0.3 \mathrm{ml}$ sample of blood was incubated at $37^{\circ} \mathrm{C}$ for $72 \mathrm{~h}$ in 2 media (RPMI-1640). For eliminating ethical concerns, informed consent document has been obtained from patient and his parents. As parts of cytogenetical study, chromosomes were prepared from cultured phytohemagglutinin-stimulated lymphocytes in prometaphase and metaphase and stained according to standard protocols. Standard techniques for the cultivation of lymphocytes from peripheral blood of patients were used and the preparations were treated with trypsin to obtain G-banding. The analyses were performed on 50 cells. Evaluation of karyotypes was done according to ISCN (2005) standards (Figure 2).

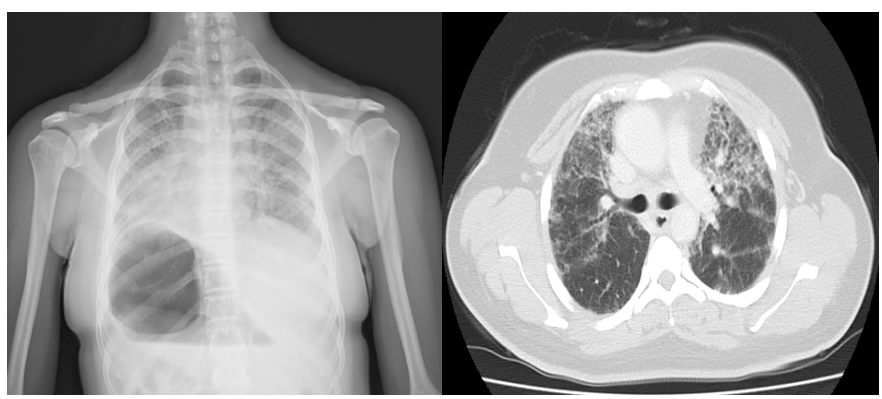

Figure 1. Chest $\mathrm{x}$-ray and thorax $\mathrm{CT}$ of the patient
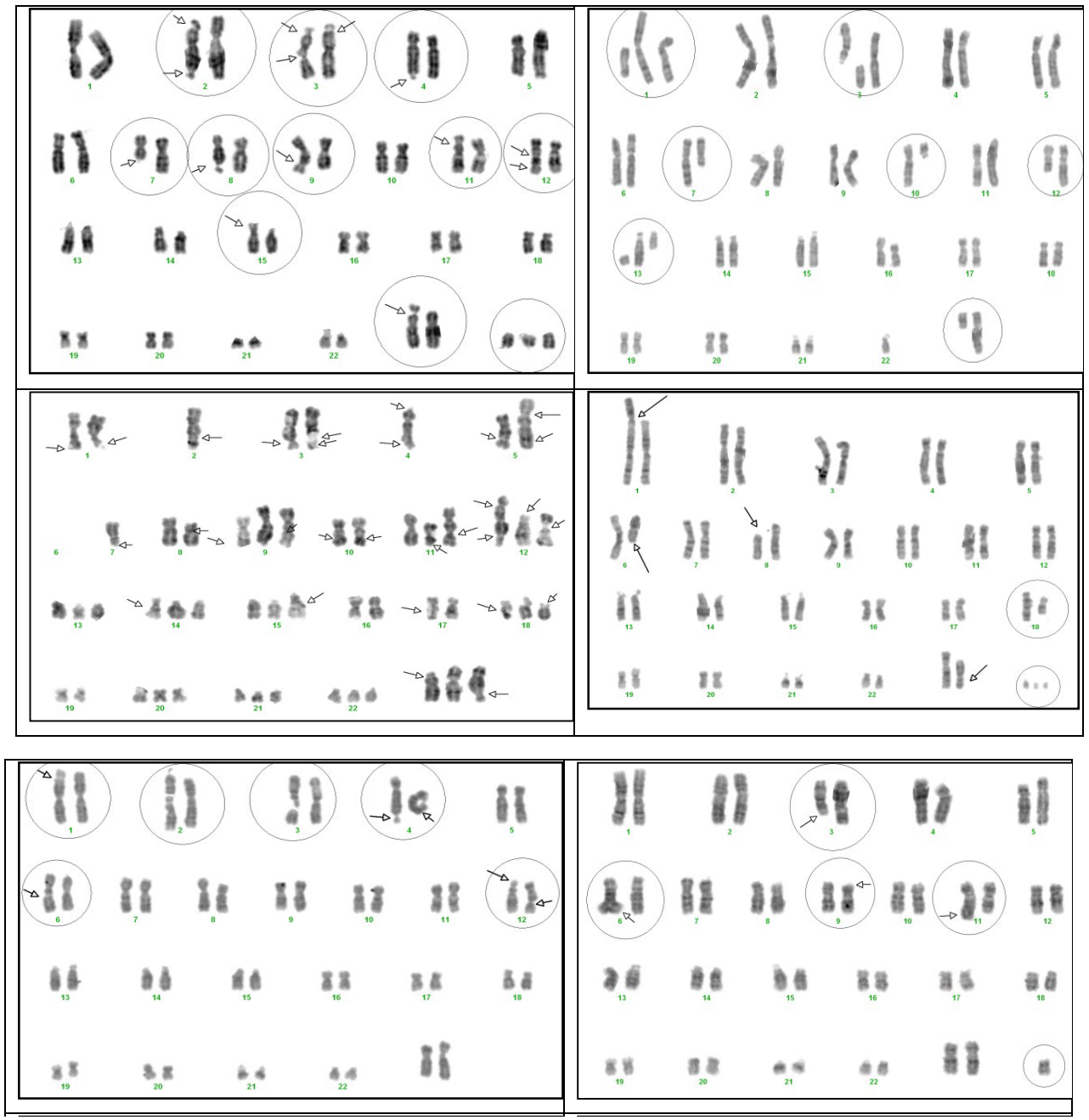


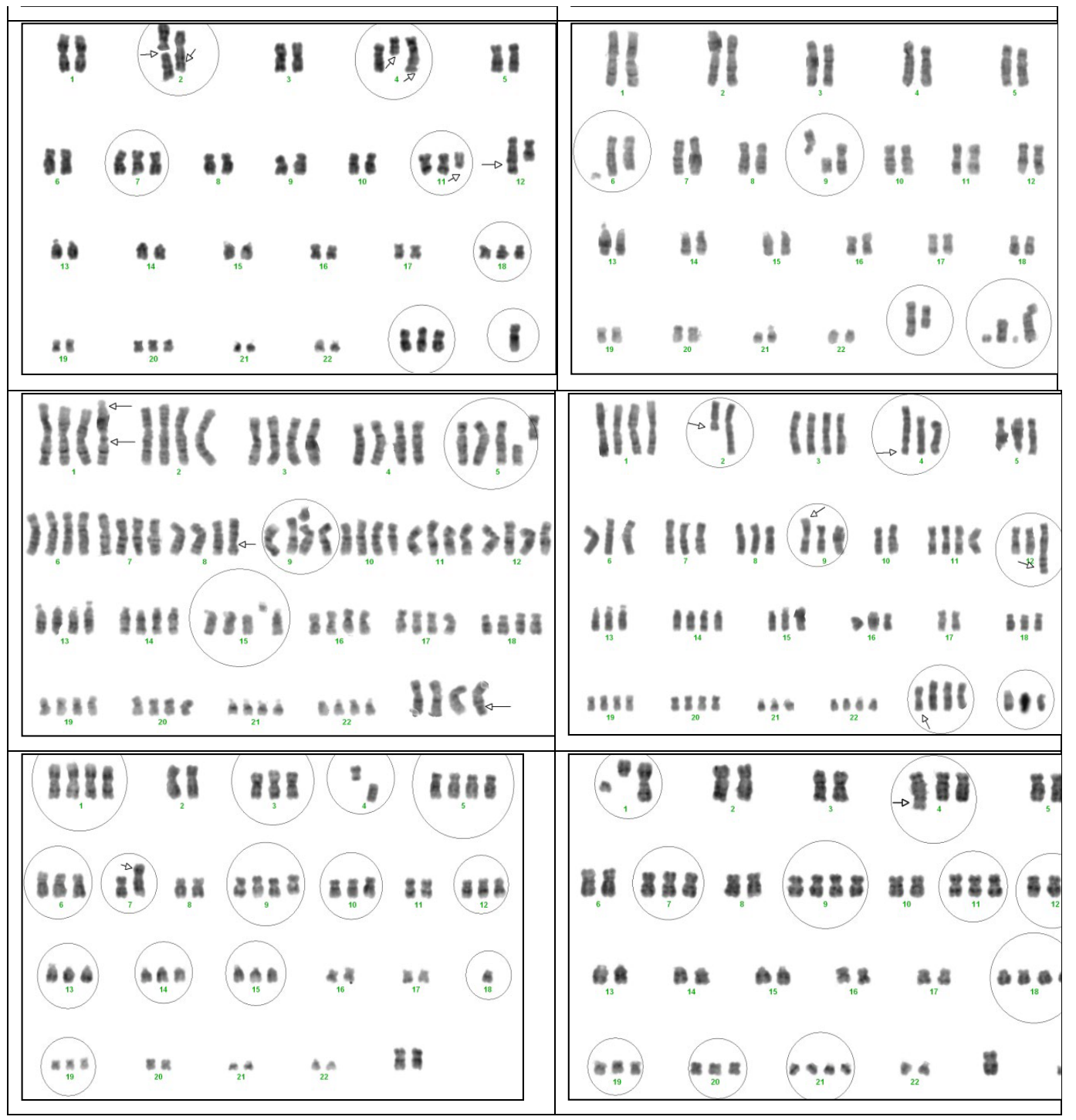

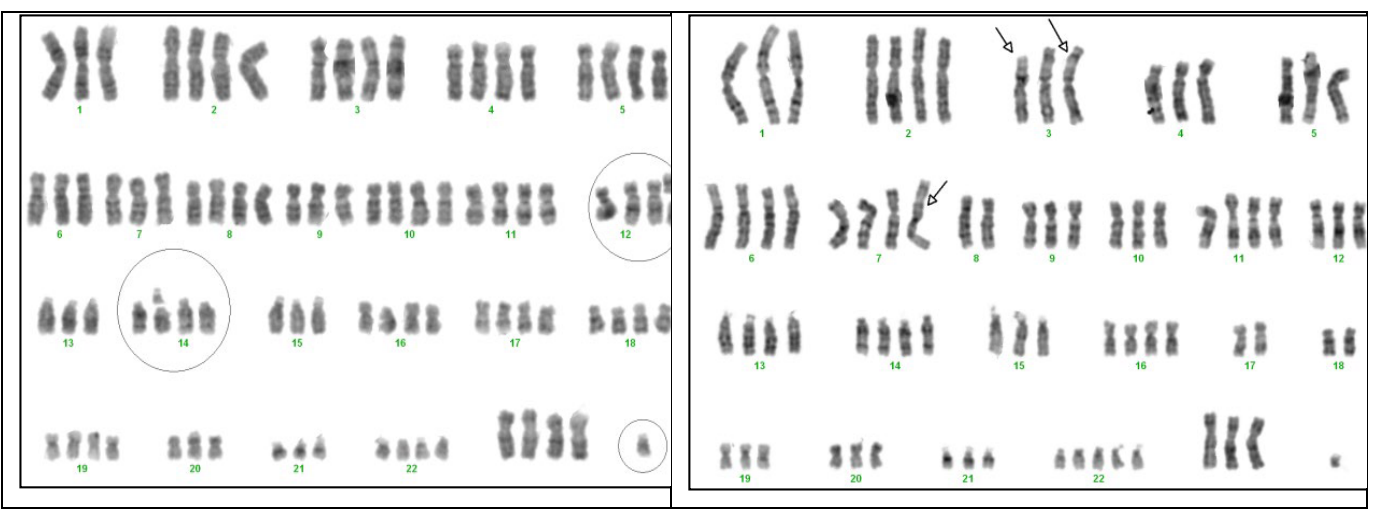

Figure 2. The appearance of some abnormal karyotypes in the patient 


\section{Results}

A total of 3 individuals from the same family members were analyzed, the cytogenetic findings in the blood of the girl and the parents were presented in Table 1 . There was at least one or more structural and/or numerical CAs in a cell of the patient. The numerical and structural aberrations were found in $94.3 \%$ abnormal cells of 53 cells analyzed in the blood. However, the karyotype results were normal in $5.7 \%$ ( 3 cells) of 53 cells of the patient. The ratio of numerical CAs was $64.2 \%$ (poliploidies, 26.7\%). These cytogenetic findings of the girl were showed in Table 1 . Structural aberrations usually consisted of fragile sites (FS), deletions, translocation, marker and acentric chromosomes, breaks and duplications in various chromosomes. Numerical aberrations were monosomies or trisomies and polyploidies of various chromosomes. These CAs were a very serious and very important genetic instability. Both numerous numerical and structural aberrations were found in the same cells, and these aberrations are shown in Table 1.

Both structural and numerical changes were also found in the mother. The aberrations were found in $40 \%$ of 50 analyzed cells (Table 1). There was a significant difference in the total chromosome abnormalities between the patient and the parents determined by the $\mathrm{x} 2$ test $(\mathrm{P}<0.001)$. In the mother, the $50 \%$ of the abnormalities were numerical aberrations, and 50\% were structural. Numerical sex CAs included 4 (5.8\%) with 45 , X, 3 (4.3\%) with 47 , XXY, and 4 (5.8\%) with structural chromosome X. The karyotype results were abnormal in $14 \%$ of 50 analyzed cells of the father. The ratio of FS and numerical aberrations was $12 \%$ and $2 \%$, respectively (Table 1 ).

\section{Discussion}

Genetics balance of human life is very important. We have 46 chromosomes. Most of CAs are harmless, a few are catastrophic. Since the chromosomes contain genes that are needed for our growth and development, it makes sense that we cannot grow and develop successfully if any chromosomes are missing. Most CAs are so harmful that the embryo or fetus does not survive long enough to be born. Many many pregnancies end in miscarriage, and many of these are caused by CAs-either numerical differences (too many or too few) or structural differences. In the present study, there were at least one or too many structural and/or numerical CAs in a cell of a person. These CAs were found in $94.3 \%$ of cells analyzed, and only the $5.7 \%$ of karyotypes were normal. These CAs are quite serious damages. Normally, such a person should have to be alive with so much genetic imbalances. Could this much genetic damages be compatible with life, and can the person live to the 23 age? Another result emerging from our study; some chromosomes in a cell enters mitosis others do not. This situation can not be compared to our current knowledge. Why some chromosomes are duplicated while others are not? Or is there a natural selection for chromosomes in cell? One of the fundamental challenges facing the cell is to accurately copy its genetic material to daughter cells. Repair of DNA damage or accurate DNA replication would be meaningless if chromosomes were not properly segregated and equally inherited during cell division. Defects in chromosome segregation increase the rate of chromosomal instability during mitosis, leading to aneuploidy. Similarly, chromosomal instability can lead to failure of cytokinesis owing to unresolved sister chromatids or to the presence of chromatin bridges at the intercellular canal that connects the two daughter cells, resulting in polyploidy [2]. This also shows that so much genetic damage in a person could affect the normal proliferation of chromosomes in mitosis. Because, the chromosome replication pathway governs accurate and unhindered replication of DNA, and a chromosome segregation pathway preserves the correct number of chromosomes during cell division $[3,4]$.

In the present study, the most common abnormalities of the patient have shown an increased incidence of autosomal aneuploidy, deletions (loss of genetic material), chromatid breaks, marker and acentric chromosomes, but only with atypical facial and growth retardation. The majority of human CAs occur in the autosomal chromosomes. Most of these abnormalities are monosomies or trisomies. However, the rate of chromosomal gains can lead to aneuploidy was termed chromosomal instability. At the same time, mother and father's mother had five miscarriages, respectively. This miscarriage history of the family is very meaningful. All fetuses with autosomal monosomies spontaneously abort early in pregnancy. Likewise, almost all fetuses with autosomal trisomies die before birth. Because, the genetic balance is severely distorted. The chromosomal instability phenotype is characterized by the gross rearrangement of chromosomes. Common CAs included the loss or gain of whole chromosomes or chromosome fragments, and the amplification of chromosome segments. Numerical aberrations of sex chromosomes come in anticipation by live birth. Despite that, fetuses with all autosomal numerical irregularities outside chromosome 13, 18 and 21 numerical deviations terminate spontaneously. The genetic balance is distorted due to the increase or lack of numerous genes in the trunk. The genes on the chromosomes are needed in exactly the correct amount in order to work correctly. Many genes cause the cell to make proteins of various kinds, and these are needed in the correct amounts. Some genes function by instructing other genes to turn on and off at the right moment, and these instructions need to be precise, accurate and sensitive.

Most frequently, a loss of genetic material in the form of deletions also can be observed in our case. Solid tumors exhibit chromosomal rearrangements resulting in gain or loss of multiple chromosomal loci. Disregulation generally leads to a gene's overexpression or provides a proliferative advantage. Scientists have hypothesized that the primary pathogenetic changes in cancer result from balanced chromosome rearrangements, while the secondary changes that occur during cancer progression are from unbalanced changes [5]. Cancer cells generally gain multiple types of CAs during tumor progression, including rearrangements, deletions, and duplications. As a result, the genome becomes progressively more unstable. However, chromosomal instability could accelerate the rate of loss of heterozygosity of a tumour suppressor gene and/or effectively amplify an oncogene by duplicating the chromosome on which it lies, thus contributing to tumorigenesis. Loss of large regions of a chromosome can lead to the inactivation of tumour suppressor genes, whereas amplification of chromosomal regions might promote tumorigenesis by the activation of proto-oncogenes, or by the induction of multidrug resistance after cytostatic drug treatment $[3,4]$. A different type of gross chromosomal aberration that is often observed in tumours is the translocation, in which chromosome arms are exchanged. These rearrangements can be associated with the deregulation of gene expression or the fusion of two genes that then acquire oncogenic potential. In the present study, the most common abnormalities of the patient have also shown an increased incidence of autosomal aneuploidies. Aneuploidy is also feature of cancers that are usually associated with poor prognosis. Father's two brothers and a sister also died from cancer in the family.

In the present study, FSs were found to be most frequently involved in structural abnormalities. FSs are suggested to predispose an individual to specific translocations and deletions in vivo. We consider 
Table 1. Karyotype in the analyzed cells of the patient, mother and father

\begin{tabular}{|c|c|}
\hline Cells & Karyotypes \\
\hline & The patient (Girl) \\
\hline 1. & $46, \mathrm{XX}, \mathrm{fra}(4 \mathrm{q} 33)$ \\
\hline 2. & 46,XX,del(6q13-qter), del(Xq28-qter) \\
\hline 3. & $93, \mathrm{XXXX}, \operatorname{der}(10) \mathrm{t}(4 ; 10)(\mathrm{q} 13 ; \mathrm{p} 24)$ \\
\hline 4. & $45, \mathrm{XX},-13, \operatorname{del}(18 \mathrm{q} 22$-qter) \\
\hline 5. & $47, \mathrm{XX},+\operatorname{mar}, \operatorname{dic}(4)$ \\
\hline 6. & $46, \mathrm{XX}, \operatorname{del}(4 \mathrm{q} 21$-qter) \\
\hline 7. & $42, \mathrm{XX},-1(\mathrm{x} 2),-2,-20, \mathrm{t}(1 ; 4)(\mathrm{q} 12 ; \mathrm{q} 34), \mathrm{t}(5 ; 20)(\mathrm{q} 31 ; \mathrm{p} 13), \operatorname{del}(9 \mathrm{q} 22,2-\mathrm{qter})$ \\
\hline 8. & $64, \mathrm{XX},+3,+4,+5,+6,+8,+9,+10,+11,+12,+13,+14,+15,+16,+19(\mathrm{x} 2),+21(\mathrm{x} 2),+22(\mathrm{x} 2), \mathrm{t}(17 ; 18)(\mathrm{q} 21 ; \mathrm{p} 11,3)$ \\
\hline 9. & $59, \mathrm{XX},+1(\mathrm{x} 2),+2,-4,+5(\mathrm{x} 2),+6(\mathrm{x} 2),-7,+9,+11,+12,+13,+14,+15,-18,+19,+20,+$ ace, del $(4 \mathrm{q} 25$-qter $)$ \\
\hline 10. & $46, \mathrm{XX}, \operatorname{chtb}(11 \mathrm{p} 11)$ \\
\hline 11. & $48, \mathrm{XX},+\operatorname{ace}(\mathrm{x} 2), \operatorname{del}(16 \mathrm{q} 23$-qter $)$ \\
\hline 12. & $93, \mathrm{XXXX},+20, \operatorname{del}(9 \mathrm{q} 13$-qter $)$ \\
\hline 13. & $46, X X, f r a(8 q 22), f r a(18 q 23)$ \\
\hline 14. & $46, X X, \operatorname{fra}(6 \mathrm{q} 21,3)$ \\
\hline 15. & $64, \mathrm{XXX},+1,+4,+6(\mathrm{x} 2),+7(\mathrm{x} 2),+8,+9,+10(\mathrm{x} 2),+12(\mathrm{x} 2),+17,+18,+19,+20(\mathrm{x} 2),+\mathrm{X}$, fra $(4 \mathrm{q} 31,3)$, fra $(11 \mathrm{q} 23,2)$ \\
\hline 16. & $47, X X,+21, \operatorname{dup}(7 q), \operatorname{del}(\mathrm{Xq} 25$-qter $)$ \\
\hline 17. & $91, \mathrm{XXXX}, \mathrm{t}(8,14)(\mathrm{q} 24,3 ; \mathrm{q} 11,2)$ \\
\hline 18. & $46, \mathrm{XX}, 4 \mathrm{p}+$ \\
\hline 19. & $70, \mathrm{XXX},+1,-2,+3(\mathrm{x} 3),+4,+5(\mathrm{x} 2),+7(\mathrm{x} 2),+9(\mathrm{x} 2), 10,+12,+13(\mathrm{x} 2),+14,+15,+17,+18,+20,+21,+22(\mathrm{x} 3),+\mathrm{X}, \operatorname{der}(3)(3 ; ?)(\mathrm{q} 21 ; ?)$ \\
\hline 20. & $45, \mathrm{XX},+9,-20, \operatorname{der}(4)(4 ; 6)(\mathrm{q} 31 ; \mathrm{q} 13), \operatorname{del}(4 \mathrm{q} 32-\mathrm{qter})$ \\
\hline 21. & $93, \mathrm{XXXX},+\mathrm{Y}(?)$ \\
\hline 22. & $49, \mathrm{XX},+\mathrm{mar},+\mathrm{Y}(?), \operatorname{der}(3)(3 ; ?)(\mathrm{q} 27 ; ?), \operatorname{fra}(17 \mathrm{q} 21)$ \\
\hline 23. & $45, \mathrm{XX},-2, \operatorname{chtbr}(1 \mathrm{p} 22), \operatorname{chtbr}(3 \mathrm{q} 22), \operatorname{del}(7 \mathrm{q} 22-\mathrm{qter}), \operatorname{der}(11), \operatorname{del}(12 \mathrm{q} 21-\mathrm{qter}), \operatorname{chtbr}(13 \mathrm{q} 22), \operatorname{del}(\mathrm{Xq12q-ter}), \operatorname{del}(10 \mathrm{q} 11-\mathrm{qter})$ \\
\hline 24. & $\begin{array}{l}87, \mathrm{XXXX},+1,+2(\mathrm{x} 2),+3(\mathrm{x} 2),+4(\mathrm{x} 2),+5(\mathrm{x} 2),+6,+7,+8(\mathrm{x} 2),+9,+10(\mathrm{x} 2),+11(\mathrm{x} 2), 12(\mathrm{x} 2),+13,+14(\mathrm{x} 2),+15,+16(\mathrm{x} 2),+17(\mathrm{x} 2),+18(\mathrm{x} 2),+19(\mathrm{x} 2),+20,+21,+22(\mathrm{x} 2),+\mathrm{X}(\mathrm{x} 2),+\mathrm{mar}, \\
\operatorname{chrbr}(12 \mathrm{q} 12), \operatorname{chrbr}(14 \mathrm{q} 12)\end{array}$ \\
\hline 25. & $76, \mathrm{XXX},+1,+2(\mathrm{x} 2),+3,+4,+5,+6(\mathrm{x} 2),+7(\mathrm{x} 2),+9,+10,+11(\mathrm{x} 2),+12,+13(\mathrm{x} 2),+14(\mathrm{x} 2),+15,+16(\mathrm{x} 2),+19,+20,+21,+22(\mathrm{x} 3),+\mathrm{X},+\mathrm{mar}, \mathrm{t}(3 ; 7)(\mathrm{p} 21,2 ; \mathrm{p} 22)$, fra $(3 \mathrm{p} 25)$ \\
\hline 26. & $49, \mathrm{XX},+18,+\operatorname{ace}(\mathrm{x} 3), \mathrm{t}(1 ; \mathrm{X})(\mathrm{p} 36,2 ; \mathrm{p} 11,2), \mathrm{t}(8 ; \mathrm{X})(\mathrm{p} 11,2 ; \mathrm{p} 13), \mathrm{t}(18 ; 18)(\mathrm{q} 22 ; \mathrm{q} 13.1)$, del$(6 \mathrm{q} 16-\mathrm{qter})$ \\
\hline 27. & $92, X X X X, f r a(1 p 36,1), \operatorname{fra}(1 \mathrm{q} 25), \operatorname{chrbr}(5 \mathrm{q} 15)$, fra(8q22), $\operatorname{chrbr}(9 \mathrm{p} 13), \operatorname{chrbr}(15 \mathrm{q} 11)$, fra(Xq22) \\
\hline 28. & $46, X X, f r a(1 p 22,3), f r a(18 q 21), \operatorname{del}(6 q 1--q t e r)$, fra(10p13) \\
\hline 29. & $52, \mathrm{XX},+?,+\operatorname{ace}(\mathrm{x} 3), \operatorname{chrbr}(6 \mathrm{q} 25), \operatorname{chrbr}(9 \mathrm{q} 22), \operatorname{del}(\mathrm{Xq} 22-\mathrm{qter})$ \\
\hline 30. & $46, X X, t(2 ; 16)(q 31 ; p 13,3)$, fra $(4 q 33)$ \\
\hline 31. & $47, \mathrm{XX},+$ mar,del(3q22-qter), t(3;11)(q22-ter;q21), t(6;11)(q22;q21), del(9p-),qr(6), \\
\hline 32. & $46, \mathrm{XX}, \mathrm{t}(22 ; ?)(\mathrm{p} 11 ; ?)$ \\
\hline 33. & $46, \mathrm{XX}$ \\
\hline 34. & $59, \mathrm{X},+4,+7,+9(\mathrm{x} 2),+11,+12,+18(\mathrm{x} 2),+19,+20,+21(\mathrm{x} 2),+\operatorname{mar}(\mathrm{x} 3), \mathrm{t}(1 ; 4)(\mathrm{q} 23 ; \mathrm{q} 35)$ \\
\hline 35. & $92, \mathrm{XXXX}, \operatorname{chrbr}(3 \mathrm{q} 24,2)$, fra(Xq26), 12q+ \\
\hline 36. & $46, X X, f r a(2 q 13)(x 2), \operatorname{chtbr}(3 q 27), f r a(7 q 22)$, fra $(X q 23)$ \\
\hline 37. & 46,XX,fra(1q36,1),chrb(2p22), chrbr(3q21), fra(4q33)(x2),fra(6q13), fra(12p13), chrbr(12q22) \\
\hline 38. & $87, \mathrm{XXXX},-2,-9,-18,-19,-1$, fra(10p13), fra(Xq26) \\
\hline 39. & 46,XX \\
\hline 40. & $49, \mathrm{XX},+18,+\operatorname{mar}(\mathrm{x} 2), \mathrm{fra}(\mathrm{Xq} 27), \mathrm{fra}(17 \mathrm{q} 21)$ \\
\hline 41. & $44, \mathrm{XX},-8,-18,-19$ \\
\hline 42. & $46, X X, f r a(4 q 33)$, fra $(6 q 23)$ \\
\hline 43. & $49, \mathrm{XX},+21,+\operatorname{ace}(\mathrm{x} 2), \operatorname{chrbr}(8 \mathrm{p} 23), \operatorname{der}(12) \mathrm{t}(12 ; ?)(\mathrm{p} 15 ; ?)$ \\
\hline 44. & $46, \mathrm{XX}$ \\
\hline 45. & $44, \mathrm{XX},-8,-19, \operatorname{der}(5)(\mathrm{p} ?)$ \\
\hline 46. & $47, \mathrm{XX},+$ ace, $\operatorname{del}(3 \mathrm{p} 22$-pter $)$ \\
\hline 47. & $40, \mathrm{XX},-3,-6,-10,-14,-17,-22, \operatorname{del}(2 \mathrm{q} 33-\mathrm{qter})$ \\
\hline 48. & 46, XX, $\operatorname{der}(9) \operatorname{dup}(9 \mathrm{p})$ \\
\hline 49. & $47, X X,-10,+(?)(x 2)$, fra(4q22), fra(4q35), del(11p1-pter),del(11q14,2-qter), del(Xq23-ter) \\
\hline 50. & $\begin{array}{l}\text { 86, XXXX, }+1,+2(\mathrm{x} 2),-,+4(\mathrm{x} 2),+5(\mathrm{x} 2), 6(\mathrm{x} 2),+7,+8(\mathrm{x} 2),+9,+10(\mathrm{x} 2),+11(\mathrm{x} 2),+12,+13(\mathrm{x} 2),+14(\mathrm{x} 2),+15(\mathrm{x} 3),+16(\mathrm{x} 2),+17,+18(\mathrm{x} 2),+19(\mathrm{x} 2),+20,+21,+22(\mathrm{x} 2),+\mathrm{X}(\mathrm{x} 2),+\mathrm{mar}, \\
\operatorname{der}(3)(3 \mathrm{q} 22-q \text { ter?), fra(4q35), fra(Xp21) }\end{array}$ \\
\hline 51. & $\begin{array}{l}77, \mathrm{XXXX},+1(\mathrm{x} 2),+3(\mathrm{x} 2),+4,+5,+6,+7,+8,+9,+11(\mathrm{x} 2),+12,+13,+14(\mathrm{x} 2),+15,+16,+18,+19(\mathrm{x} 2),+20(\mathrm{x} 2),+21,+22(\mathrm{x} 2),+\mathrm{X}(\mathrm{x} 2),+?(\mathrm{x} 3), \operatorname{del}(2 \mathrm{q} 23), \operatorname{der}(4) \mathrm{t}(4 ; ?)(\mathrm{q} 31 ; ?), \operatorname{der}(9) \\
\mathrm{t}(\mathrm{p} 24 ; ?), \operatorname{der}(12) \mathrm{t}(12 ; 7)(24, \mathrm{q} ; \mathrm{p} 13), \operatorname{del}(\mathrm{Xq} 22)\end{array}$ \\
\hline 52. & $44, \mathrm{XX},-8,-13, \operatorname{der}(1)(\mathrm{p} 36,1 ; 8 ?), \operatorname{chrbr}(3 \mathrm{p} 21.1)$ \\
\hline \multirow[t]{5}{*}{53.} & $\begin{array}{l}\text { 49,XX,+ace (x3), fra(2p23), fra(2q25), fra(3p25), chrb(3q13,2), fra(3p25), fra(4q25), del(7q22), fra(8q24,1), der(9)t(9;?)(q32;?), der(11)t(11;?)(p11,2;?),fra(12q15), } \\
\text { fra(12q24,1), 15p+, chrb(Xp21,2) }\end{array}$ \\
\hline & Mother \\
\hline & $\begin{array}{l}\text { 46,XX,chrb(11p15); 46,XX,fra(1q42); 48,XX,+11,+?,der(17)t(17;?)(q25;?),fra(5q25); } \\
\text { 44,XX,-10,-14; 46,XX,del(14q32.1),fra(1p32); 41,XX,der(2)t(2;18)(q35;p11.3),der(2)t(2;9); } \\
\text { 45,XX,-21; 46,XX,fra(Xq27); 46,XX,fra(2q21),fra(2q31); 44,XX,-5,-20,der(5)t(5q;?); 46,XX,fra(2q31); 45,XX,-16; 46,XX,fra(11p15); 46,X,-X,+mar; 41,X,-X,-8,-11,-17,-- } \\
\text { 19; 47,XXX; 47,XXX; 47,XXX; 46,XXX,-13,fra(2q31); 46,Xi(Xq) }\end{array}$ \\
\hline & 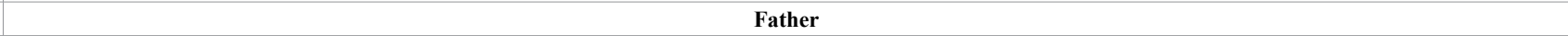 \\
\hline & 45,XY,-22; fra(1q23); fra(1q32); fra(Xq26); fra(5q23); fra(7q21); gap(13q13) \\
\hline
\end{tabular}


that these FS as potential loci for harboring genes that are important in the development and progression of canser. Thus, there was also cancer history of our family. Therefore, FSs are known to be associated with genes that relate to tumorigenesis [6]. Other studies also have shown that FS and associated genes are frequently deleted or rearranged in many cancer cells and have clearly demonstrated their importance in genome instability in cancer [7]. Furthermore, CAs were also found in $40 \%$ of the mother'cells. This suggests that chromosomal damage has passed from mother to daughter at a higher rate. The mother had also evidenced of significant disease. Thus, for those with missing or duplicated chromosome material, the effects will vary, but symptoms could include physical and/or health problems, learning disability and maybe challenging behaviour. The combination and severity of symptoms will vary depending on which parts of chromosomes are involved and the way in which they are different.

\section{Conclusion}

Dozens of chromosomal damages were observed in a cell as in this patient. There is a relationship between chromosome damage and symptoms of dyspnea, cough. With very high genetic damage, he survived until 23 years of age. Chromosome analysis of patients with cough must be done. Accordingly, the form of treatment should be determined. In addition, we cannot explain the different number of deviations of chromosomes in the same cell with our current information. This issue needs to be investigated and explained by experts.

\section{References}

1. van Gent DC, Hoeijmakers JH, Kanaar R (2001) Chromosomal stability and the DNA double-stranded break connection. Nat Rev Genet 2: 196-206.

2. Storchova Z, Pellman D (2004) From polyploidy to aneuploidy, genome instability and cancer. Nat Rev Mol Cell Biol 5: 45-54. [Crossref]

3. Branzei D, Foiani M (2010) Maintaining genome stability at the replication fork. Nat Rev Mol Cell Biol 11: 208-219. [Crossref]

4. Gordon DJ, Resio B, Pellman D (2012) Causes and consequences of aneuploidy in cancer. Nat Rev Genet 13: 189-203. [Crossref]

5. Mitelman F, Mertens F, Johansson B (2005) Prevalence estimates of recurrent balanced cytogenetic aberrations and gene fusions in unselected patients with neoplastic disorders. Genes, chromosomes \& cancer 43: 350-366.

6. Matsuyama A, Croce CM, Huebner K (2004) Common fragile genes. Eur J Histochem 48: 29-36. [Crossref]

7. Debacker K, Kooy RF (2007) Fragile sites and human disease. Hum Mol Genet 16 Spec No. [Crossref]

Copyright: (C2019 Demirhan O. This is an open-access article distributed under the terms of the Creative Commons Attribution License, which permits unrestricted use, distribution, and reproduction in any medium, provided the original author and source are credited. 